\title{
FAKTOR-FAKTOR YANG MEMPENGARUHI PENGGUNAAN KARTU KREDIT SYARIAH PADA PEGAWAI WANITA PT. RIAU MULIA MITRA MEDIKA
}

\author{
Dian Permata Putri, Wahyi Busyro \\ Universitas Muhammadiyah Riau \\ Universitas Muhammadiyah Riau \\ dianpermataputri@gmail.com,wahyi.busyro@umri.ac.id
}

\begin{abstract}
ABSTRAK
Dewasa ini untuk melakukan transaksi, dapat digunakan berbagai sarana pembayaran, mulai dari cara yang paling tradisional, sampai dengan cara yang paling modern sekalipun. Pada awal mula sebelum dikenalnya uang sebagai alat pembayaran, setiap transaksi pembayaran dilakukan melalui cara barter. Perkembangan selanjutnya, ditemukan cara yang paling efisien dan efektif untuk melakukan transaksi pembayaran yaitu dengan menggunakan "uang". Penggunaan uang juga mengalami berbagai hambatan, terutama jika penggunaannya dalam jumlah besar. Hambatannya yang pertama adalah resiko membawa uang tunai terutama dalam jumlah besar. Disamping resiko membutuhkan tempat, juga resiko keamanan. Pegawai wanita di PT Riau Mulia Mitra Medika rata-rata memiliki berbagai jenis kartu kredit syariah dari beberapa bank berbeda. Setiap kali melakukan kegiatan transaksi dimana saja kebiasaan menggunakan kartu kredit tidak pernah hilang, mulai dari berbelanja kebutuhan sehari-hari hingga barang mewah. Penelitian ini mengambil 3 faktor yang akan diteliti pengaruhnya terhadap penggunaan kartu kredit syariah yaitu faktor gaya hidup, budaya, kelompok referensi. Populasi yang digunakan pada penelitian sebanyak 70 pegawai wanita dan sampel diambil melalui PurposiveSampling yaitu 40 pegawai wanita. Faktor yang paling dominan berpengaruh terhadap penggunaan kartu kredit syariah adalah faktor kelompok referensi.
\end{abstract}

Kata Kunci: Kartu Kredit Syariah, Pegawai Wanita

\section{PENDAHULUAN}

PT Mulia Mitra Medika memiliki pegawai mayoritas adalah wanita. Pegawai wanita di PT Riau Mulia Mitra Medika rata-rata memiliki berbagai jenis kartu kredit dan kartu kredit syariah dari beberapa bank berbeda. Setiap kali melakukan kegiatan transaksi dimana saja kebiasaan menggunakan kartu kredit tidak pernah hilang, mulai dari berbelanja kebutuhan sehari-hari hingga barang mewah. Terkadang hanya untuk makan saja mereka lebih memilih membayar menggunakan kartu kredit konvensional maupun syariah dibanding dengan uang tunai karena mereka beranggapan bahwa dengan menggunakan kartu kredit terkesan lebih highclass.

Beberapa pegawai wanita ada yang menggunakan kartu kredit syariah hanya untuk keperluan yang mendesak dan ketika tidak ada uang tunai seperti biaya kesehatan yang harus dikeluarkan untuk keluarganya, dan ada juga yang menggunakannnya sebagai modal usaha untuk membeli barang-barang modal. Tetapi kebanyakan menggunakan hanya untuk membeli barang mewah dan kemudian mereka dapat mencicilnya dalam jangka waktu tertentu. Tidak jarang beberapa pegawai wanita ada yang tidak sanggup membayar tagihan kartu kredit syariahnya sampai dengan jatuh tempo hingga 
mengganggu kegiatan kerja dikantor terutama bagian humas yang setiap hari ditelepon dengan nada yang kurang baik karena ada karyawan yang tidak dapat membayar tagihannya. Tetapi hal ini tidak membuat jera para pegawai wanita untuk membuat dan menggunakan kartu kredit.

Berdasarkan pada fakta-fakta dan data diatas, maka penulis tertarik untuk mengadakan penelitian tentang faktor-faktor yang mempengaruhi penggunaan kartu kredit syariah pada pegawai wanita PT Mulia Mitra Medika.

\section{Pengertian Kartu Kredit}

Kartu kredit adalah alat pembayaran pengganti uang tunai, berbentuk kartu yang memberikan fasilitas kredit kepada pemiliknya, dimana saat jatuh tempo dapat dibayarkan dengan jumlah minimum dan sisanya dijadikan kredit (Sumarto, 2007).

Pengertian tentang kartu kredit juga dapat ditemukan pada ketentuan Bank Indonesia No.11/11/PBI/2009 tentang Penyelenggaraan Kegiatan Alat Pembayaran dengan Menggunakan Kartu (APMK) yang dimaksud dengan kartu kredit adalah APMK yang dapat digunakan untuk melakukan pembayaran atas kewajiban yang timbul dari suatu kegiatan ekonomi, termasuk transaksi pembelanjaan dan atau penarikan tunai, dimana kewajiban pemegang kartu kredit terpenuhi terlebih dahulu oleh Acquirer atau penerbit, dan pemegang kartu berkewajiban untuk melakukan pembayaran pada waktu yang disepakati baik dengan pelunasan sekaligus ataupun dengan pembayaran secara angsuran(Bank Indonesia, 2016).

\section{Jenis Jenis Kartu Kredit Syariah}

Masing-masing penerbit kartu kredit memiliki kelebihan dan kekurangannya. Secara umum, ada 3 jenis berdasarkan besaran limitnya yaitu sebagai berikut:

a) Kartu Kredit Silver : Dengan limit terendah Rp 3 juta - Rp 5 Juta, merupakan jenis kartu kredit yang paling banyak digunakan oleh pegawai bergaji terbawah.

b) Kartu Kredit Gold : Dengan limit sedang Rp 5 juta - Rp 20 Juta,merupakan jenis kartu kredit yang banyak dimiliki oleh pegawai setingkat manajer dan supervisor.

c) Kartu Kredit Platinum : Dengan limit Rp 20 juta sampai dengan tidak terbatas (unlimited). merupakan jenis kartu kredit yang dimiliki oleh pebisnis, pemilik perusahaan atau direktur.

\section{Alasan Penggunaan Kartu Kredit Syariah}

Bagi pemegang kartu kredit syariah dengan memiliki kartu kredit diharapkan dapat memberikan berbagai keuntungan antara lain:

1) Kemudahan berbelanja

Artinya belanja dengan cara kredit memberikan kemudahan, sehingga nasabah tidak perlu membawa uang tunai untuk melakukan setiap transaksi pembayaran, cukup menunjukkan kartu dan menandatangani bukti pembelanjaan

2) Kemudahan memperoleh uang tunai

Nasabah dalam hal ini setiap saat dapat memperoleh uang tunai selama 24 jam dan 7 hari kerja diberbagai tempat-tempat strategis termasuk hari libur. Dengan demikian memudahkan nasabah untuk memenuhi keperluan uang tunai secara mendadak, seperti dalam kondisi tertimpa musibah, sakit atau kondisi darurat lainnya.

3) Bonafiditas

Bagi sebagian kalangan memegang kartu kredit memberikan kesan bonafiditas, sehingga memberikan kebanggan tersendiri (Kasmir, 2008:178). 


\section{METODOLOGI}

Penelitian ini dilaksanakan pada PT Riau Mulia Mitra Medika di Pekanbaru. Populasi menurut Sugiyono (2014:80) adalah wilayah generalisasi yang terdiri atas objek/subjek yang mempunyai kualitas dan karateristik tertentu yang diterapkan oleh peneliti untuk dipelajari dan kemudian ditarik kesimpulannya.Dalam penelitian ini populasi yang menjadi objek/subjek penelitian adalah seluruh pegawai wanita PT Riau Mulia Mitra Medika yang berjumlah 76 orang. Menurut Sugiyono (2014:85) PurposiveSampling adalah teknik penentuan sampel dengan pertimbangan tertentu.Sehingga ditetapkan karakteristik subjek penelitian sebagai berikut:

1. Berusia $21-40$ tahun

2. Memiliki kartu kredit Syariah

3. Memiliki penghasilan diatas Rp. 2.500.000,00 per bulan

4. Sudah bekerja minimal 1 tahun.

Pengambilan ukuran sampel menurut Roscoe dalam buku Research Methods For Business (yang dikutip dalam buku sugiyono, 2014:90) yaitu "Bila dalam penelitian akan melakukan analisis dengan multivariate (korelasi atau regresi ganda misalnya), maka jumlah anggota sampel minimal 10 kali dari jumlah variabel yang diteliti. Maka jumlah sampel yang dapat diambil adalah:

$$
\text { Jumlah Sampel }=10 \times 4=40
$$

Teknik pengumpulan data yang digunakan dalam penelitian ini adalah Kuesioner (angket). Penelitian ini menggunakan Uji Validitas, Uji Reliabilitas dan tekhnik analisis data yang digunakan adalah uji asumsi klasik, analisis regresi linier berganda, Uji koofisien determinasi, Uji T dan Uji F.

\section{HASIL PENELITIAN}

Pada pengujian validitas, semua indikator emperik pada masing-masing variabel penelitian mempunyai $r_{\text {hitung }}>r_{\text {table }}$ sehingga indicator emprik dari masingmasing variabel gaya hidup achievers, budaya, kelompok referensi dan penggunaan kartu kredit dinyatakan valid. Demikian halnya dengan reliabilitas, menunjukkan semua nilai cronbach alpha> 0,600 sehingga variabel-variabel tersebut dinyatakan reliable.

Salah satu syarat untuk bisa digunakannya analisis regresi berganda adalah semua variabel mempunyai distribusi normal.Uji normalitas data dengan menggunakan uji kolmogrov-sminov. bahwa semua angka signifikan Kolmogorov smirnov > 0,05 sehingga distribusinya dinyatakan normal.

Semua variabel independen nilai tolerance $>0,10$ dan nilai $\mathrm{VIF}<10,0$ sehingga dinyatakan tidak terjadi multikolinieritas antar variabel independen.

Semua variabel independen memiliki nilai Sig. > 0,05 sehingga dinyatakan tidak ada Heteroskedastisitas dalam residual.

Dari hasil analisis regresi tersebut maka dapat diketahui bahwa variabel paling dominan berpengaruh terhadap penggunaan kartu kredit pada pegawai wanita PT Riau 
Mulia Mitra Medika adalah kelompok referensi. Hal ini disebabkan karena variabel kelompok referensi mempunyai nilai angka yang terbesar jika dibandingkan dengan variabel lainnya.

Adjusted $R$ Square adalah 0,416. Hal ini menunjukkan pengertian bahwa penggunaan kartu kredit (Y) dipengaruhi sebesar $41,6 \%$ oleh variabel gaya hidup $\left(\mathrm{X}_{1}\right)$, Budaya $\left(\mathrm{X}_{2}\right)$, dan kelompok referensi $\left(\mathrm{X}_{3}\right)$, sedangkan sisanya $100 \%-41,6 \%=$ $58,4 \%$ dipengaruhi oleh faktor-faktor yang lain.

Uji t digunakan untuk mengetahui besarnya pengaruh dari setiap variabel independen dengan probabilita satu arah dengan hipotesis : "terdapat hubungan yang positif antara gaya hidup terhadap penggunaan kartu kredit". Hasil uji t pada penelitian ini dapat dilihat pada tabel 4.14 dengan penjelasan sebagai berikut:

1) Variabel Gaya Hidup $\left(X_{1}\right)$

Hasil pengujian dengan SPSS untuk variabel gaya hidup $\left(\mathrm{X}_{1}\right)$ terhadap penggunaan kartu kredit $(\mathrm{Y})$ diperoleh nilai $\mathrm{t}_{\text {hitung }}=2,439$ dengan $\mathrm{t}_{\text {tabel }}=\mathrm{n}$ $-1(40-1=39)$ dengan $\alpha=5 \%(0,05)$ nilai $t_{\text {tabel }}=1,685$ dapat dikatakan $t_{\text {hitung }}>t_{\text {tabel }}(2,439>1,685)$, maka $\mathrm{H} 1$ diterima dan $\mathrm{H} 0$ ditolak yang berarti terdapat hubungan yang positif antara gaya hidup terhadap penggunaan kartu kredit. Dengan tingkat signifikan $(\alpha)=0,20: 2=0,10$ dengan batas signifikasi $(\alpha)=0,05$ maka dapat disimpulkan bahwa $\alpha>0,05$ maka $\mathrm{H} 0$ diterima dan $\mathrm{H} 1$ ditolak yang berarti tidak terdapat hubungan yang signifikan antara gaya hidup terhadap penggunaan kartu kredit.

2) Variabel Budaya $\left(X_{2}\right)$

Hasil pengujian dengan SPSS untuk variabel budaya $\left(\mathrm{X}_{2}\right)$ terhadap penggunaan kartu kredit $(Y)$ diperoleh nilai $t_{\text {hitung }}=1,847$ dengan $t_{\text {tabel }}=n$ $-1(40-1=39)$ dengan $\alpha=5 \%(0,05)$ nilai $t_{\text {tabel }}=1,685$ dapat dikatakan $t_{\text {hitung }}>t_{\text {tabel }}(1,847>1,685)$, maka $\mathrm{H} 1$ diterima dan $\mathrm{H} 0$ ditolak yang berarti terdapat hubungan yang positif antara budaya terhadap penggunaan kartu kredit. Dengan tingkat signifikan $(\alpha)=0,73: 2=0,365$ dengan batas signifikasi $(\alpha)=0,05$ maka dapat disimpulkan bahwa $\alpha>0,05$ maka $\mathrm{H} 0$ diterima dan $\mathrm{H} 1$ ditolak yang berarti tidak terdapat hubungan yang signifikan antara budaya terhadap penggunaan kartu kredit.

3) Variabel Kelompok Referensi $\left(\mathrm{X}_{3}\right)$

Hasil pengujian dengan SPSS untuk variabel kelompok referensi $\left(\mathrm{X}_{3}\right)$ terhadap penggunaan kartu kredit $(\mathrm{Y})$ diperoleh nilai $\mathrm{t}_{\text {hitung }}=1,723$ dengan $\mathrm{t}_{\text {tabel }}=\mathrm{n}-1(40-1=39)$ dengan $\alpha=5 \%(0,05)$ nilai $\mathrm{t}_{\text {tabel }}=1,685$ dapat dikatakan thitung $>t_{\text {tabel }}(1,723>1,685)$, maka H1 diterima dan $\mathrm{H} 0$ ditolak yang berarti terdapat hubungan yang positif antara kelompok referensi terhadap penggunaan kartu kredit. Dengan tingkat signifikan $(\alpha)=0,94: 2$ $=0,47$ dengan batas signifikasi $(\alpha)=0,05$ maka dapat disimpulkan bahwa $\alpha>0,05$ maka $\mathrm{H} 0$ diterima dan $\mathrm{H} 1$ ditolak yang berarti tidak terdapat hubungan yang signifikan antara kelompok referensi terhadap penggunaan kartu kredit. 
$F_{\text {hitung }}$ sebesar 10,273 sedangkan $F_{\text {tabel }}$ pada tabel distribusi dengan tingkat kesalahan $5 \%(0,05)$ adalah $(\mathrm{k} ; \mathrm{n}-\mathrm{k}-1)=(3 ; 40-3-1)=(3 ; 36)$ yaitu sebesar 2,87. Bila $F_{\text {hitung }}>F_{\text {tabel }}(10,273>2,87)$ maka H1 diterima dan H0 ditolak. Pada tabel diatas juga dapat dilihat bahwa nilai signifikasinya 0,000 lebih kecil dari 0,05 yang berarti secara bersama-sama (simultan) variabel gaya hidup, budaya, dan kelompok referensi berpengaruh secara positif dan signifikan terhadap penggunaan kartu kredit pada pegawai wanita dan karena nilai signifikasinya lebih kecil dari 0,05 maka model regresi dapat digunakan untuk memprediksi penggunaan kartu kredit.

\section{DISKUSI}

1. Pengaruh Gaya Hidup Achievers $\left(\mathrm{X}_{1}\right)$ Terhadap Penggunaan Kartu Kredit Syariah (Y)

Tingginya penggunaan kartu kredit syariah oleh pegawai wanita dipengaruhi oleh gaya hidupnya. Pegawai wanita cenderung memiliki gaya hidup achievers, hal ini sesuai dengan penelitian yang dilakukan oleh veronica yang menyatakan bahwa terdapat hubungan yang positif antara gaya hidup achievers dengan minat menggunakan kartu kredit syariah sebesar 26,8\%. Tingkat pengaruh gaya hidup dalam penelitian ini ditunjukkan dengan angka $28 \%$ yang memiliki nilai yang positif terhadap penggunaan kartu kredit syariah. Gaya hidup achievers dalam penelitian ini ditandai oleh tingkat kepercayaan diri yang bertambah ketika menggunakan kartu kredit syariah yang ditunjukkan dengan nilai rata-rata 3,35 yang berarti ketika para pegawai wanita menggunakan kartu kreditnya, mereka menunjukkan bahwa dengan menggunakan kartu kredit syariah sebagai suatu kebanggaan yang menyatakan bahwa mereka berhasil secara ekonomi sehingga bisa memiliki dan menggunakan kartu kredit syariah. Tetapi gaya hidup achievers tidak memiliki pengaruh yang signifikan terhadap penggunaan kartu kredit syariah karena terjadi perubahan selera, kebiasaan, dan perilaku pembelian yang dapat mengubah gaya hidup seseorang atau karena faktor-faktor lainnya.

\section{Pengaruh Budaya $\left(\mathrm{X}_{2}\right)$ Terhadap Penggunaan Kartu Kredit Syariah (Y)}

Dengan ditambahnya variabel budaya dalam penggunaan kartu kredit syariah sehingga menunjukkan angka sebesar 38,5\% setelah sebelumnya dipengaruhi oleh gaya hidup pegawai wanita tersebut. Semakin tinggi budaya (selalu mengikuti perkembangan teknologi), maka semakin tinggi penggunaan kartu kredit syariahnya. Hal ini ditunjukkan dengan nilai rata-rata penggunaan kartu kredit syariah dalam segi teknologi perbankan yang semakin canggih sebesar 6,88. Tetapi budaya tidak signifikan terhadap penggunaan kartu kredit karena budaya bersifat dinamis, yang artinya budaya akan selalu berkembang terus sesuai dengan perubahan dan perkembangan zaman dan ada faktor-faktor lain yang mempengaruhi penggunaan kartu kredit syariah.

\section{Pengaruh Kelompok Referensi $\left(\mathrm{X}_{3}\right)$ Terhadap Penggunaan Kartu Kredit syariah(Y)}

Adanya penambahan pengaruh faktor kelompok referensi dalam penggunaan kartu kredit syariah sebesar 41,6\%. Fakta dilapangan juga menunjukkan kelompok referensi dari kalangan teman-teman memiliki nilai rata-rata sebesar 4,28 yang artinya cukup memiliki pengaruh yang besar dalam penggunaan kartu kredit syariah, karena 
kelompok referensi mempengaruhi perilaku seseorang dalam pembeliaannya, dan sering dijadikan pedoman oleh konsumen untuk bertingkah laku. kelompok referensi tidak memiliki pengaruh yang signifikan dalam penggunaan kartu kredit syariah karena pengaruh keluarga dalam kelompok refensi memiliki peran yang penting dalam pengambilan keputusan.

4. Pengaruh gaya hidup achievers, budaya, dan kelompok referensi secara bersama-sama Terhadap Penggunaan Kartu Kredit Syariah (Y)

Ketika semua variabel ditambahkan maka akan menunjukkan nilai sebesar 41,6\% yang artinya semua variabel secara bersama-sama memiliki pengaruh yang positif terhadap penggunaan kartu kredit syariah. Dan dengan nilai signifikasi sebesar 0,000 yang dinyatakan bahwa secara bersama-sama variabel-variabel tersebut signifikan terhadap penggunaan kartu kredit syariah.

\section{KESIMPULAN}

Berdasarkan penelitian yang sudah dilakukan maka bisa disimpulkan bahwa faktor yang paling dominan berpengaruh terhadap penggunaan kartu kredit syariah adalah kelompok referensi, kemudian dilanjutkan dengan faktor budaya dan yang terakhir adalah faktor gaya hidup.

Penelitian selanjutnya diharapakan bisa menambahkan variabel penelitian dan sampel penelitian.

\section{DAFTAR PUSTAKA}

Bank Indonesia. (2009). Peraturan Bank Indonesia tentang Alat pembayaran dengan menggunakan kartu

Ekowati, titin. (2011). Consumer buying

Kasmir. (2008). Dasar dasar perbankan. Jakarta : Raja Grafindo Persada

Kristianti,D.S. (2014). Kartu Kredit Syariah dan Perilaku Konsumtif Masyarakat. Ahkam. Vol XIV

Schiffman. (2007). Consumer behaviour. Ninth Edition. New Jersey : Prentice hall International

Sugiyono. (2009). Statistika Untuk Penelitian. Bandung : Alfabeta

Sugiyono. (2014). Metode Penelitian Bisnis. Bandung : Alfabeta

Sumarto, A. (2011). Penggunaan Kartu Kredit dan Perilaku Belanja Kompulsif : Dampaknya pada Risiko Gagal Bayar. Jurnal Manajemen Pemasaran. Vol 6

$$
\text { و الله أعلم بالصو اب }
$$

